\title{
POVZETKI, SYNOPSES, ZUSAMMENFASSUNGEN
}

(c) BYSA

Stati in obstati $17(2021): 415-425$

https://doi.org/10.26493/2590-9754.17(34)415-425

UDC 165.74:316.74:2

\section{Gorazd Andrejč}

\section{Religiozni moralni jeziki, sekularnost in hermenevtična nepravičnost}

»Zmerni pragmatizem« Jeffreyja Stouta kot filozofski pristop k javnemu moralnemu diskurzu v versko pluralni družbi je naletel na mešane odzive $\mathrm{z}$ nasprotnih si strani razprave o sekularizmu. Po eni strani so vplivni teologi in komunitaristi (npr. Stanley Hauerwas) trdili, da Stout preveč popušča sekularistom. Po drugi strani so sekularisti (npr. Richard Rorty) menili, da je njegov vključujoči pristop do verskih utemeljitev v javnem diskurzu preveč teološki.

Pričujoči esej temelji na prepričanju, da si Stoutov poskus posredovanja med politično teologijo krščanskih komunitaristov in liberalnimi vizijami javnega diskurza npr. različicami Rortyja, Habermasa in Rawlsa - zasluži vnovično obravnavo in nadaljnjo analizo v luči novejših prispevkov na področju epistemologije demokracije ter pragmatistične filozofije jezika. V okviru te vnovične preučitve prezentiram nekaj, kar po Stoutu imenujem »zmernopragmatistična« vizija javnega moralnega diskurza, pri čemer se ukvarjam s Stoutovim opisom delovanja takšnega diskurza v zahodnih družbah, predvsem pa se v normativnem smislu zgledujem po osrednjih značilnostih Stoutovega pristopa. Trdim, da je takšna vizija prepričljiva le, če nekatera načela, ki jih Stout bodisi potrjuje bodisi predpostavlja - močno načelo verske svobode, demokratično načelo vključevanja in načelo reševanja sporov diskurzivno in ne nasilno -, postavimo v njeno središče in jih razvijemo nekoliko bolj, kot jih je v svojih delih razvil Stout sam. V ta namen sem apliciral novejše teoretične prispevke na področju epistemologije demokracije, zlasti tiste, ki sta jih opravila Elisabeth Anderson in José Medina, v kombinaciji z wittgensteinovsko-pragmatistično filozofijo verskega jezika.

Pri tem pa so v pričujočem eseju zgoraj omenjene teorije politične filozofije - zlasti Medinova teorija hermenevtične (ne)pravičnosti - aplicirane na vprašanje, ki ga neposredno ne obravnavajo ali mu ne namenjajo veliko pozornosti, namreč: kako je mogoče in treba vključiti različne verske jezike v javno moralno razpravo? Rezultat je - tako trdim - nova in močnejša različica zmerne pragmatistične vizije javnega moralnega diskurza ter obnovljen argument za sekularnost takega diskurza: javni moralni diskurz mora biti običajno (kvalificirano) sekularen tudi v družbah, kjer je večina državljanov kristjanov, saj je takšna sekularnost najbolj demokratičen način ravnanja in omogoča najpravičnejše spoštovanje verske svobode. Vendar sekularnost tu ne pomeni »zmanjšanja vere« med člani družbe niti ne nujno upada obiskov verskih objektov in drugih verskih praks, temveč »dejstvo, da udeleženci neke dane diskurzivne prakse niso v polo- 
žaju, da bi lahko privzeli kot samoumevno, da imajo njihovi sogovorniki iste religiozne predpostavke kot oni« (Stout 2004, 97).

Ključne besede: pragmatizem, religija, sekularizem, verska svoboda, etika

\section{Religious Moral Languages, Secularity, and Hermeneutical Injustice}

Jeffrey Stout's "modest pragmatism", as a philosophical approach to public moral discourse in a religiously plural society, has received a mixed response from the opposite sides of the secularism debate. On the one hand, influential theologians and communitarian thinkers (e.g. Stanley Hauerwas) have claimed that Stout concedes too much to the secularists. On the other hand, secularists (e.g. Richard Rorty) have found Stout's inclusive approach towards religious reasonings in public discourse all too theological.

This essay is based on the conviction that Stout's attempt at mediating between the political theology of Christian communitarians and the liberal visions of public discourse - say, versions by Rorty, Habermas and Rawls, respectively - deserves a re-examination and further analysis in the light of recent work in epistemology of democracy and pragmatist philosophy of language. By way of offering such re-examination, it presents what, following Stout, the author calls a "modest pragmatist" vision of public moral discourse, engaging with Stout's descriptive account of how such discourse has functioned in Western societies, but more importantly, taking inspiration from the central features of Stout's approach in a normative sense. In this essay, it is argued that such a vision is persuasive only if certain principles which Stout either affirms or presupposes a strong principle of religious freedom, a democratic principle of inclusion and a principle to settle disputes discursively and non-violently - are placed in its centre and developed somewhat further than they have been in Stout's own work. This is done by using recent theoretical works in the epistemology of democracy, especially those by Elisabeth Anderson and José Medina, in combination with Wittgensteinian-pragmatist philosophy of religious language.

In this essay, however, the above-mentioned theories of political philosophy - Medina's theory of hermeneutical (in)justice in particular - are applied to the question which they do not address directly nor pay much attention to: how can and should different religious languages be included in public moral deliberation? The result is, as the author argues, a new and stronger variant of the modest pragmatist vision of public moral discourse and a renewed argument for the secularity of such discourse: public moral discourse should normally be (qualifiedly) secular even in societies in which the majority of citizens are Christian, because such secularity is the most democratic way to proceed and enables the fairest kind of respect for religious freedom. But secularity here does not mean a "decrease in faith" among the members of society, nor necessarily a falling attendance at the houses of worship and other religious practices, but rather "the fact that participants in a given discursive practice are not in a position to take 
for granted that their interlocutors are making the same religious assumptions they are" (Stout 2004, 97).

Keywords: pragmatism, religion, secularism, religious freedom, ethics

\section{Religiöse Moralsprachen, Säkularität und hermeneutische Ungerechtigkeit}

Jeffrey Stouts „,moderater Pragmatismus“ als philosophischer Ansatz für den öffentlichen moralischen Diskurs in einer religiös pluralen Gesellschaft hat von den entgegengesetzten Seiten der Säkularismusdiskussion eine gemischte Resonanz erfahren. Einerseits argumentierten einflussreiche Theologen und Kommunitaristen (z. B. Stanley Hauerwas), dass Stout gegenüber Säkularisten viel zu nachsichtig sei. Auf der anderen Seite hielten Säkularisten (z. B. Richard Rorty) seinen inklusiven Ansatz gegenüber religiösen Begründungen im öffentlichen Diskurs für zu theologisch.

Der vorliegende Aufsatz beruht auf der Überzeugung, dass Stouts Vermittlungsversuch zwischen der politischen Theologie christlicher Kommunitaristen und den liberalen Visionen des öffentlichen Diskurses - z. B. verschiedene Varianten von Rorty, Habermas und Rawls - im Hinblick auf neueste Arbeiten zur Epistemologie der Demokratie und zur pragmatischen Sprachphilosophie eine erneute Auseinandersetzung und eine weitere Analyse verdient. Im Rahmen dieser neuerlichen Untersuchung wird erforscht, was der Autor nach Stout eine „moderat pragmatische“ Vision des öffentlichen moralischen Diskurses nennt. Die Untersuchung geht dabei der Frage nach, wie Stout die Wirkung eines solchen Diskurses in westlichen Gesellschaften beschreibt, vor allem aber nimmt sich der Autor im normativen Sinne die zentralen Merkmale von Stouts Ansatz zum Vorbild. Es wird die These aufgestellt, dass eine solche Vision nur dann überzeugend ist, wenn bestimmte Prinzipien, die Stout entweder anerkennt oder voraussetzt - das starke Prinzip der Religionsfreiheit, das demokratische Prinzip der Inklusion und das Prinzip der diskursiven statt gewaltsamen Konfliktlösung - in den Mittelpunkt gestellt und weiterentwickelt werden. Zu diesem Zweck wurden neuere theoretische Arbeiten aus dem Gebiet der Epistemologie der Demokratie, insbesondere Beiträge von Elisabeth Anderson und José Medina, in Kombination mit der Wittgensteinschen pragmatischen Philosophie der religiösen Sprache herangezogen.

Im vorliegenden Aufsatz werden die oben genannten Theorien der politischen Philosophie - insbesondere Medinas Theorie der hermeneutischen (Un)gerechtigkeit - auf die Frage appliziert, die nicht direkt angesprochen bzw. der nicht viel Aufmerksamkeit geschenkt wird, und zwar: Wie können und sollen unterschiedliche religiöse Sprachen in die öffentliche Moraldiskussion einbezogen werden? Daraus ergibt sich, so die Argumentation, eine neue und stärkere Variante der moderaten pragmatistischen Vision des öffentlichen moralischen Diskurses und ein erneutes Argument für die Säkularität eines solchen Diskurses: Der öffentliche moralische Diskurs sollte normalerweise (qualifiziert) säkular sein, selbst in Gesellschaften, in denen sich die Mehrheit der Bürger zum Christentum bekennt, denn eine solche Säkularität ist die demokratischste Handlungs- 
weise und ermöglicht die gerechteste Achtung der Religionsfreiheit. Allerdings bedeutet Säkularität in diesem Kontext weder eine „Reduktion des Glaubens" bei den Mitgliedern der Gesellschaft noch einen Rückgang der Besuche religiöser Stätten und anderer religiöser Praktiken, sondern es handelt sich um die „Tatsache, dass Teilnehmer einer bestimmten diskursiven Praxis nicht als selbstverständlich hinnehmen, dass ihre Gesprächspartner die gleichen religiösen Voraussetzungen haben wie sie selbst" (Stout 2004, 97).

Schlüsselwörter: Pragmatismus, Religion, Säkularismus, Religionsfreiheit, Ethik

UDC 37.014.511.3-055.25:274

\section{Žiga Oman \\ Medkonfesionalno sobivanje v zgodnjenovoveškem Podravju: primer protestantske dekliške šole Ane Totting $v$ času protireformacije}

Članek na podlagi najnovejših raziskav medkonfesionalnega sobivanja v zgodnjenovoveški Evropi zagovarja tezo, da so družinski, sosedski, stanovski in gospodarski odnosi omogočali tudi mirno sobivanje med katoličani in protestanti v spodnještajerskem Podravju v 16. in 17. stoletju. Prispevek je osredotočen na deželnoknežji mesti Ptuj in Maribor in pokaže, da so meščani obeh s svojimi »heretičnimi sosedi« globoko v prvo polovico 17. stoletja praviloma vzdrževali mirne odnose, kljub konfesionalnemu razdoru in državnemu preganjanju. Kaže, da je bila mariborska župnijska cerkev večji del druge polovice 16. stoletja, ko je bila tamkajšnja meščanska elita prevladujoče protestantska, »simultana«. Na sosednjem Ptuju so bili meščani enakomerneje ločeni po obeh veroizpovedih, kar se je, kot kaže, odražalo tudi v mestnem svetu, z razdelitvijo svétniških mest med katoličane in protestante po "pariteti«. Proti koncu 16. stoletja je medkonfesionalno sobivanje $\mathrm{v}$ obeh mestih ogrozila deželnoknežja protireformacija, vendar so se lokalne oblasti v pregon in spreobračanje svojih protestantskih sosedov vključile šele po najmočnejšem pritisku državnih konfesionalizacijskih prizadevanj. Vendar, ker je bil deželni knez zaposlen zlasti s politično podreditvijo notranjeavstrijske protestantske opozicije, je njegova rekatolizacijska politika kmalu izgubila zalet, zlasti na lokalni ravni. V prizadevanjih za ohranitev svoje avtonomije in avtoritete, ki ju je ogrožala deželnoknežja politika, so mestne oblasti skušale "prikriti« obstoj svojih »sektaških « sosedov, da bi preprečile nadaljnje vmešavanje. Ta politika je v obeh mestih koreninila $\mathrm{v}$ strpnosti ali vsaj ravnodušnosti večine katoličanov do njihovih protestantskih sosedov, ki je bila utemeljena na različnih družbenih odnosih, ki so premoščali konfesionalne razlike med meščani, zlasti meščansko elito. To je oviralo uspeh protireformacijskih odlokov do zgodnjih tridesetih let 17. stoletja, na dolgi rok pa ni moglo uspeti. Pomemben primer te kljub vsemu dolgožive "praktične strpnosti« je bila protestantska šola za dekleta Ane Totting na Ptuju v zgodnjem 17. stoletju. Šoli je kljub pritiskom deželnoknežje 
reformacije skoraj eno desetletje preživetje omogočala Anina čezkonfesionalna družinska in medsosedska solidarnost.

Ključne besede: medkonfesionalno sobivanje, reformacija, protireformacija, Ana Totting, Podravje

\section{Confessional Coexistence in Early Modern Podravje: The Case of Anna Totting's Protestant School for Girls during the Counter-Reformation}

Based on recent research on confessional coexistence in early modern Europe, this paper argues that familial, neighbourly, class, and economic relations also enabled peaceful coexistence between Catholics and Protestants during the sixteenth and seventeenth century in the Lower Styrian Podravje region. The article focuses on the princely towns of Ptuj and Maribor, demonstrating that despite the confessional rift and state persecution, the burghers in both towns generally maintained peaceful relations with their "heretic" neighbours well into the first half of the seventeenth century. It seems that the Maribor parish church was a simultaneum during much of the second half of the sixteenth century, when the town's elite was predominantly Protestant. In neighbouring Ptuj, burghers were more equally divided between the confessions, which seems to have been reflected in the city council as well, with the division of seats between Catholics and Protestants according to "parity". By the end of the sixteenth century, confessional coexistence in both towns was threatened by the Princely Counter-Reformation, although it was only under the greatest pressure of the state's confessionalization efforts that the local authorities joined in the persecution and proselytization of their Protestant neighbours. However, as the land sovereign was primarily engaged in the political subordination of the Inner-Austrian Protestant opposition, his recatholization policies soon lost momentum, especially at the local level. Struggling to maintain their autonomy and authority, which were jeopardized by princely policies, magistrates tried to keep their "sectarian" neighbours "secret" to prevent further interventions. The policy in both towns also stemmed from tolerance, or at least indifference, of most Catholics towards their Protestant neighbours, which was rooted in various social relations bridging the confessional gap among the burghers, especially their elite. This impeded the fruition of counter-reformatory ordinances until the early 1630s, but it could not succeed in the long run. A prominent example of this nonetheless long-lived "practical tolerance" was Anna Totting's Protestant school for girls in the early seventeenth-century Ptuj. Despite the pressure of the Princely Counter-Reformation, Anna's interconfessional familial and neighbourly solidarity enabled the school's survival for almost a decade.

Keywords: confessional coexistence, Reformation, Counter-Reformation, Anna Totting, Podravje 


\section{Interkonfessionelle Koexistenz in der Region Podravje in der Frühen Neuzeit: Der Fall der protestantischen Mädchenschule von Anna Totting in der Gegenreformation}

Im Beitrag wird auf der Grundlage der neuesten Forschungen zum interkonfessionellen Zusammenleben im Europa der Frühen Neuzeit die These aufgestellt, dass familiäre, nachbarschaftliche, ständische und wirtschaftliche Beziehungen in der untersteirischen Region Podravje im 16. und 17. Jahrhundert auch ein friedliches Zusammenleben zwischen Katholiken und Protestanten ermöglichten. Der Beitrag konzentriert sich auf die landesfürstlichen Städte Ptuj (Pettau) und Maribor (Marburg an der Drau) und zeigt, dass die Bürger beider Städte mit ihren „,häretischen Nachbarn“ bis tief in die erste Hälfte des 17. Jahrhunderts trotz konfessioneller Spaltung und staatlicher Verfolgung in der Regel friedliche Beziehungen pflegten. Es scheint, dass die Pfarrkirche in Maribor während der meisten Zeit in der zweiten Hälfte des 16. Jahrhunderts, als die bürgerliche Elite überwiegend protestantisch war, „simultan“ war. Im benachbarten Ptuj war das Bürgertum gleichmäßiger unter den Konfessionen aufgeteilt, eine Tatsache, die sich anscheinend auch im Stadtrat widerspiegelte, in dem Sitze nach der „Parität" zwischen Katholiken und Protestanten verteilt wurden. Gegen Ende des 16. Jahrhunderts wurde das interkonfessionelle Zusammenleben in beiden Städten durch die landesfürstliche Gegenreformation gefährdet, doch schlossen sich die lokalen Machthaber der Verfolgung und Bekehrung ihrer protestantischen Nachbarn erst unter größtem Druck der staatlichen Konfessionalisierungsbemühungen an. Da aber der Landesfürst vor allem mit der politischen Unterordnung der innerösterreichischen protestantischen Opposition beschäftigt war, verlor seine Rekatholisierungspolitik vor allem auf lokaler Ebene schnell an Kraft. Um ihre von der landesfürstlichen Politik bedrohte Autonomie und Autorität zu wahren, versuchten die Stadtbehörden, die Existenz ihrer "sektiererischen" Nachbarn zu „verbergen“, um weitere Eingriffe zu verhindern. Eine solche Politik in beiden Städten wurzelte in der Toleranz oder zumindest Gleichgültigkeit der meisten Katholiken gegenüber ihren protestantischen Nachbarn, die auf unterschiedlichen sozialen Beziehungen begründet war, welche die konfessionellen Unterschiede beim Bürgertum, insbesondere der bürgerlichen Elite, überbrückten. Dies verhinderte bis Anfang der 163oer-Jahre den Erfolg gegenreformatorischer Verordnungen, konnte aber auf Dauer nicht erfolgreich sein. Ein prominentes Beispiel für die lange Jahre vorhandene „praktische Toleranz" war die protestantische Mädchenschule von Anna Totting im frühen 17. Jahrhundert in Ptuj. Obwohl die landesfürstliche Gegenreformation Druck ausübte, ermöglichte die interkonfessionelle familiäre und nachbarschaftliche Solidarität, dass die Schule fast ein Jahrzehnt lang ihrer Tätigkeit nachgehen konnte.

Schlüsselwörter: interkonfessionelles Zusammenleben, Reformation, Gegenreformation, Anna Totting, Podravje-Region 
UDC $725.945(497.4)$

Marjana Dolšina Delač

Javni spomeniki na Velikolaškem: Ob sedemdeseti obletnici postavitve spomenika Primožu Trubarju na Rašici

Primož Trubar je kljub nesporni vlogi pri razvoju slovenskega knjižnega jezika in tvornemu prispevku $\mathrm{k}$ formiranju slovenskega naroda zaradi nesprejemljivega verskega ozadja svojega javnega delovanja in pisanja stoletja dolgo ostajal v senci prepoznavnejših naslednikov. Prvi javni spomenik mu je prineslo šele dleto Franca Bernekerja, ki je leta $1910 \mathrm{z}$ impozantno figuro Trubarja za govorniškim pultom ob vhodu v ljubljanski park Tivoli (in danes pred stavbo Moderne galerije) v slovenskem kiparstvu široko odprl vrata formirajočemu se modernizmu. Na rodni Rašici, ki je bila v tem času kot večina slovenskega podeželja še obarvana z gorečim katolištvom, so morali na spomenik počakati vse do druge polovice 2o. stoletja. Takrat so ob štiristoletnici izida prve slovenske knjige leta 1951 postavili in leta 1952 slavnostno odkrili spomenik Primožu Trubarju. Arhitektonsko celoto z obeliskom arhitekta Vinka Glanza dopolnjuje Trubarjeva bronasta reliefna podoba, ki je nastala v ateljeju medaljerja Vladimirja Štovička. V letu 2021 mineva sedemdeset let od ureditve tega obeležja, ki je bilo v povojnem času, torej času množičnega postavljanja spomenikov narodnoosvobodilnemu boju, izjemoma posvečeno protestantskemu pridigarju in piscu verskih besedil. Obletnica ponuja priložnost za izpostavljanje vprašanja statusa in funkcije javnih spomenikov na širšem območju Velikih Lašč, ki je poleg Primoža Trubarja v svet poslalo še druga pomembna imena, danes ustoličena predvsem na področjih jezikoslovja, književnosti in likovne kritike: Frana Levstika, Jožeta Javorška in Josipa Stritarja. Pregledni oris javnih spomenikov, ki so na Velikolaškem nastali ob pomembnih obletnicah teh velikih možz, skuša posredovati podobo kolektivnega spomina lokalne skupnosti, ki skoznje manifestira svoj odnos do preteklosti in vrednoti njihovo zapuščino kot neprecenljivo kulturno dediščino.

Ključne besede: Primož Trubar, Fran Levstik, Josip Stritar, Jože Javoršek, javni spomeniki

\section{Public monuments in Velike Lašče and its surroundings: On the occasion of the seventieth anniversary of the monument to Primož Trubar in Rašica}

Primož Trubar played an indisputable role in the consolidation of the Slovene formal language and contributed significantly to the formation of the Slovene nation. Nevertheless, due to unacceptable religious background of his public activities and writing, he was overshadowed by his prominent successors for centuries. His first public statue was erected only in 1910, when Franc Berneker sculpted an imposing figure of Trubar behind a pulpit at the entrance of the Tivoli Park (today, the statue stands opposite of 
the Modern Gallery building) in Ljubljana and thus paved the way for emerging modernism in Slovene sculpture. In Trubar's native village Rašica, where ardently Catholic ideas were still prevalent at that time, the monument was set up as late as the second half of the twentieth century. On the occasion of the four-hundredth anniversary of the first book published in the Slovene language, a memorial to Primož Trubar was erected in 1951 and ceremoniously unveiled in 1952. A stone architectural structure with an obelisk, designed by architect Vinko Glanz, is complemented by Trubar's bronze relief portrait made in the studio of the medallist Vladimir Štoviček. In 2021, seventy years have passed since it was built in the post-war era, when new monuments in Slovenia were mostly dedicated to the national liberation struggle, which makes a memorial to a Protestant preacher and writer of religious texts truly exceptional. The anniversary offers an opportunity to expose the question of the status and the role of public sculptures in Velike Lašče and its surroundings, which in addition to Primož Trubar contributed some other great names, related to the fields of linguistics, literature and art criticism: Fran Levstik, Jože Javoršek and Josip Stritar. The overview of the public monuments in this area that were erected to commemorate important anniversaries of the four great men seeks to illustrate the collective memory of the members of local community, whose relationship to the past and appreciation of the mentioned figures' legacy as invaluable cultural heritage manifest itself in these monuments.

Keywords: Primož Trubar, Fran Levstik, Josip Stritar, Jože Javoršek, public monuments

\section{Öffentliche Denkmäler in Velike Lašče und seiner Umgebung: Ein Beitrag anlässlich des 70. Jahrestages der Errichtung des Trubar-Denkmals in Rašica}

Primož Trubar (Primus Truber) spielte eine unbestreitbare Rolle bei der Entwicklung der slowenischen Schriftsprache und trug maßgeblich zur Bildung der slowenischen Nation bei. Dennoch blieb er aufgrund des inakzeptablen religiösen Hintergrunds seiner öffentlichen Tätigkeit und seines Schreibens jahrhundertelang im Schatten seiner prominenteren Nachfolger. Sein erstes öffentliches Denkmal verdiente sich Trubar erst 1910, als Franc Berneker eine imposante Trubar-Figur hinter einem Rednerpult am Eingang des Tivoli-Parks (heute vor dem Gebäude der slowenischen Modernen Galerie) in Ljubljana schuf, womit die Tür für die aufkommende Moderne in der slowenischen Bildhauerkunst geöffnet wurde. In seinem damals noch stark katholisch geprägten Geburtsdorf Rašica wurde sein Denkmal erst in der zweiten Hälfte des 20. Jahrhunderts errichtet. Anlässlich des 400. Jahrestages der Veröffentlichung des ersten Buches in slowenischer Sprache wurde 1951 ein Primož-Trubar-Denkmal errichtet und 1952 feierlich enthüllt. Eine steinerne Architekturstruktur mit einem Obelisken, entworfen von dem Architekten Vinko Glanz, ergänzt Trubars Bronzerelief, das im Atelier des Medailleurs Vladimir Štoviček entstanden ist. Im Jahr 2021 sind siebzig Jahre vergangen 
seitdem in der Nachkriegszeit das Trubar-Denkmal errichtet wurde, also in einer Zeit, als neue Denkmäler in Slowenien hauptsächlich dem nationalen Befreiungskampf gewidmet waren. In diesem Kontext war das einem protestantischen Prediger und Verfasser religiöser Texte gewidmete Denkmal in Rašica wirklich außergewöhnlich. Bezüglich des Jubiläums ergibt sich die Gelegenheit, die Frage nach dem Status und der Rolle der öffentlichen Denkmäler in der weiteren Umgebung von Velike Lašče zu beleuchten, von wo aus neben Primož Trubar auch einige andere große Namen aus den Bereichen Linguistik, Literatur und Kunstkritik in die Welt gingen: Fran Levstik, Jože Javoršek und Josip Stritar. Mit der vorliegenden Übersicht über die öffentlichen Denkmäler in diesem Gebiet, die anlässlich wichtiger Jahrestage aller vier großen Männer errichtet wurden, wird der Versuch unternommen, das Bild des kollektiven Gedächtnisses der lokalen Gemeinschaft zu vermitteln, die dadurch ihren Bezug zur Vergangenheit manifestiert und das Erbe der bedeutenden Landsmänner als unschätzbares kulturelles Erbe würdigt.

Schlüsselwörter: Primus Truber, Fran Levstik, Josip Stritar, Jože Javoršek, öffentliche Denkmäler

\section{UDC 274(497.4)}

\section{Vincenc Rajšp}

\section{Protestantizem na Slovenskem v prvih šestih desetletjih 19. stoletja}

Razprava predstavi prikazovanja in pojmovanja reformacije in protestantizma od konca 18. do začetka šestdesetih let 19. stoletja. Protestantizem je v Habsburški monarhiji doživel nov razvoj predvsem po tolerančnem patentu cesarja Jožefa II. leta 1781, ko so ponovno oživele slovenske protestantske fare v Prekmurju in edina slovenska kriptoprotestantska skupnost $\mathrm{v}$ Zagoričah na Koroškem. Novo prelomnico je prineslo leto 1848, ko je v Avstrijskem cesarstvu pojem enakopravnosti zajel jezike in tudi veroizpovedi.

Za slovenski prostor je za ta čas značilen strpen odnos med katoličani in protestanti na kulturnem in nacionalnem področju. Slomškovo gledanje na kulturni pomen slovenskih protestantov, pa tudi še trajajoča nemška jezikovna tolerantnost sta omogočali strpno sožitje.

Podrobneje je predstavljena knjiga o Primožu Trubarju avtorja Wilhelma Sillema, ki je izšla leta 1861 in doslej v zgodovinopisju in biografijah Primoža Trubarja (z izjemo Jožeta Rajhmana) ni bila zapažena in upoštevana. Delo je pomembno, saj daje odlično sliko prelomnice takratnega razvoja gledanja na reformacijo. Sillem poudarja pomen Primoža Trubarja in drugih slovenskih protestantov za slovenski kulturni in izobraževalni razvoj. Delo posebej ne napada papeža. Svojo ost proti rimskokatoliški cerkvi uperi v nedejavnost oglejskega patriarhata, ki na svojem področju ne dohaja razvoja tiska glagolskih in cirilskih knjig za slovansko bogoslužje na južnoslovanskem prostoru, tako v pravoslavni kot katoliški Cerkvi. 
Velik pomen daje Sillem kulturi in izobraževanju, vendar s poudarkom na nemški kulturi in izobraževanju (geografsko, ne le jezikovno), ki bi ga bili deležni, če bi bila reformacija na Kranjskem uspešna, tudi ostali južni Slovani. To bi naj dvignilo kulturno raven nad tisto, ki so je bila ta slovanska ljudstva deležna pod italijanskim vplivom.

Ključne besede: reformacija, protestantizem, medkonfesionalno sobivanje, Primož Trubar, 19. stoletje

\section{Protestantism in the Slovene Lands in the First Six Decades of the $19^{\text {th }}$ Century}

The paper presents the representations and conceptions of Reformation and Protestantism from the late 18th century to the early 186os. Protestantism in the Habsburg Monarchy underwent a new development mainly after the Patent of Toleration by emperor Joseph II in 1781, when the Slovene Protestant parishes in Prekmurje and the only Slovene Crypto-Protestant community in Zagoriče in Carinthia reappeared. A new turning point came in 1848, when the concept of equality in the Austrian Empire encompassed languages as well as religions.

The Slovene area at that time was characterized by a tolerant relationship between Catholics and Protestants in the cultural and national spheres. Slomšek's view on the cultural significance of Slovene Protestants, as well as at the time still present German linguistic tolerance, enabled peaceful coexistence.

The paper introduces in more detail the book about Primož Trubar by Wilhelm Sillem, which was published in 1861 and has heretofore not been noticed and considered in the historiography and biographies of Primož Trubar (with the exception of Jože Rajhman). The work is important as an excellent illustration of the changed perception of the Reformation at that moment in the development of its representations. Sillem emphasizes the importance of Primož Trubar and other Slovene Protestants for Slovene cultural and educational development. In the book, he does not specifically attack the Pope. Rather, his opposition to the Roman Catholic Church is aimed at the inactivity of the Patriarchate of Aquileia, which did not keep up with the development of the printing of Glagolitic and Cyrillic books for Slavic worship in the 16th-century South Slavic area, neither in the Orthodox nor in the Catholic Church.

Sillem places great importance on culture and education, but with an emphasis on German culture and education (geographically, not only linguistically), which would have benefited other southern Slavs, if the Reformation in Carniola had been successful. In his opinion, this would have raised the cultural level above the one which these Slavic nations had under Italian influence.

Keywords: Reformation, Protestantism, confessional coexistence, Primož Trubar, 19th century 


\section{Protestantismus in den slowenischen Gebieten in den ersten sechs Jahrzehnten des 19. Jahrhunderts}

In der Abhandlung werden Darstellung und Erfassung der Reformation und des Protestantismus vom Ende des 18. bis zum Anfang der 6oer-Jahre des 19. Jahrhunderts besprochen. Besonders nach dem Toleranzpatent Kaiser Josephs II. im Jahr 1781 erfuhr der Protestantismus in der Habsburgermonarchie eine neue Entwicklung. Damals kam es zu einem erneuten Aufleben der slowenischen protestantischen Kirchengemeinden im Raum Prekmurje (Übermurgebiet) und der einzigen slowenischen kryptoprotestantischen Gemeinde in Zagoriče (Agoritschah) in Kärnten. Einen weiteren Wendepunkt stellt das Jahr 1848 dar, als sich der Gleichberechtigungsgedanke im Kaisertum Österreich auch auf Sprachen und Konfessionen ausweitete.

$\mathrm{Zu}$ dieser Zeit war der slowenische Raum von einem toleranten Verhältnis zwischen Katholiken und Protestanten im kulturellen und nationalen Bereich geprägt. Die Auffassung von Bischof Slomšek von der kulturellen Bedeutung der slowenischen Protestanten sowie die noch anhaltende deutsche Sprachtoleranz ermöglichten ein friedliches Miteinander.

Im Beitrag wird ausführlich das 1861 erschienene Buch über Primož Trubar (Primus Truber) von Wilhelm Sillem behandelt, das bisher sowohl in der Geschichtsschreibung als auch in den Trubar-Biographien, ausgenommen der Biographie von Jože Rajhman, wenig Beachtung erfahren hat. Es handelt sich um ein wichtiges Werk, da es einen ausgezeichneten Einblick in die Veränderungen bietet, zu denen es in der damaligen Zeit angesichts des Reformationsverständnisses gekommen war. Sillem betont die Bedeutung von Trubar und anderen slowenischen Protestanten für die slowenische Kultur- und Bildungsentwicklung. Ferner wird der Papst im behandelten Werk nicht ausdrücklich angegriffen; die Kritik gegen die römisch-katholische Kirche richtet sich eher auf die Untätigkeit des Patriarchats von Aquileia, das beim Druck glagolitischer und kyrillischer Bücher für den slawischen Gottesdienst sowohl in der orthodoxen als auch in der katholischen Kirche im südslawischen Raum offensichtlich zurückblieb.

Sillem legt großen Wert auf Kultur und Bildung, wobei er jedoch besondere Betonung auf deutsche Kultur und Bildung (geografisch, nicht nur sprachlich) legt, wovon auch die restlichen Südslawen hätten profitieren können, wenn die Reformation in Krain erfolgreich gewesen wäre. Dadurch hätte man die Kultur der slawischen Völker auf ein höheres Niveau heben können, als dies unter dem italienischen Einfluss der Fall gewesen ist.

Schlüsselwörter: Reformation, Protestantismus, interkonfessionelles Zusammenleben, Primus Truber, 19. Jahrhundert

Prevod povzetkov v angleščino: Višnja Jerman Prevod povzetkov v nemščino: Tanja Žigon Bibliografska obdelava: Mojca Novak 